\title{
Hypocrisy in stewardship: An ethical reading of Malachi 3:6-12 in the context of Christian stewardship
}

\begin{abstract}
Authors:
B. Onoriodẹ Bọlọjẹ ${ }^{1}$

Alphonso Groenewald ${ }^{1}$

Affiliations:

${ }^{1}$ Department of Old

Testament Studies,

University of Pretoria,

South Africa

\section{Note:}

B. Onoriode Boloje is

a doctoral student at

the Department of Old

Testament Studies, Faculty

of Theology, University

of Pretoria, South Africa

with Prof. Dr Alphonso

Groenewald as supervisor.
\end{abstract}

\section{Correspondence to:}

Alphonso Groenewald

Email:

alphonso.groenewald@

up.ac.za

Postal address:

Private Bag X20, Hatfield

0028, South Africa

Dates:

Received: 25 Oct. 2013

Accepted: 23 Feb. 2014

Published: 09 July 2014

How to cite this article: Boloje, B.O. \& Groenewald, A., 2014, 'Hypocrisy in stewardship: An ethical reading of Malachi 3:6-12 in the context of Christian stewardship', HTS Teologiese Studies/Theological Studies 70(1), Art. \#2086, 11 pages. http://dx.doi.org/10.4102/ hts.v70i1.2086

\section{Copyright:}

(C) 2014. The Authors. Licensee: AOSIS OpenJournals. This work is licensed under the Creative Commons Attribution License.
The biblical concept of stewardship has been subjected to some misunderstanding. Each time the word stewardship is mentioned, the meaning that easily comes to mind is that of money. One of the means through which Christians express their appreciation to God is through dedicated and trustworthy stewardship. In the book of Malachi the focus on the tithe in particularly in the fifth disputation oracle (3:6-12) is closely associated with the issue of disrespect for the Lord. The people's perspective with respect to and use of their wealth and/ or personal effects was simply a symptom of the viability of their covenant relationship with Yahweh. An acknowledgement of Yahweh's ultimate ownership and/or proprietorship over all things, his generosity and faithfulness in juxtaposition to the deceitfulness of the people as demonstrated by Malachi serves as enough motivation for total Christian stewardship. This article highlights the economic reality of Yehud during Malachi's day, the intricacies of the prophet's accusations of hypocrisy concerning the tithe, and in an attempt to be dispassionate as well as careful, the article concludes by emphasising some underlying principles with regard to Christian stewardship which will serve as a reminder to Christians about their ethical responsibility.

\section{Introduction}

The biblical concept of stewardship has been subjected to some misunderstanding. Each time the word stewardship is mentioned, the meaning that easily comes to mind is that of money. Whilst it is true that one of the means through which Christians express their appreciation to God is through dedicated and trustworthy stewardship, the focus on the tithe in the book of Malachi particularly in the fifth disputation oracle (3:6-12) is closely associated with the issue of disrespect for the Lord. The people's perspective with respect to and use of their wealth and/ or personal effects was simply a symptom of the viability of their covenant relationship with Yahweh. Their attitudes indicate a lack of love, commitment and depth. An acknowledgement of Yahweh's ultimate ownership and/or proprietorship over all things, his generosity and faithfulness in juxtaposition to the deceitfulness of the people as demonstrated by Malachi serves as enough motivation for total Christian stewardship. The term stewardship literally denotes:

to take care of something entrusted to one, to manage another's estate or property, the charge committed to one. We have been given stewardship over our time, energy, talents, values, feelings, behaviour, money and all other things. (Van der Walt 2012:3)

Christian stewardship has to be viewed from different perspectives and with varying lenses. Whilst it should include money, stewardship of money is only a fraction of our total Christian stewardship. Giving on the one side is only a part of our stewardship of money, and tithing and offering are only parts of our stewardship of giving:

Christian stewardship involves the totality of the believer's life - his time, his money, his talents, his energy, his family, his business, his home, etc. When a believer begins to take total stewardship seriously, tithing is seen as only one facet of the Christian's accountability unto God. Negligence in tithing is not simply a money problem; it is a people problem. (Davis 1987:97)

Thus total Christian stewardship involves consecration of the life of the individual and resources to the service of God and humanity. In this regard, if one allows his stewardship to fall behind, it does indicate to some extent a lack of love, commitment and depth. All aberrant sentiments that will hinder appropriate Christian stewardship are frequently emphasised against in the Scriptures. ${ }^{1}$ Thus denial to give of our resources in a manner that is pleasing unto God can both

1.In the book of Proverbs (3:9), one reads: 'Honor the Lord with your wealth, with the first-fruits of all your crops'. The Apostle Paul instructs Galatians believers, ' $a$ ] nyone who receives instruction in the word must share all good things with his instructor' (GI 6:6). James denounced the wealthy for their self-centeredness and unfaithfulness, "[c]ome now, you rich, weep and howl for your miseries which are coming upon you. Your riches have rotted and your garments have become moth-eaten. Your gold and your silver have rusted; and their rust will be a witness against you and will consume your flesh like fire ... You have lived luxuriously on the earth and led a life of wanton pleasure; you have fattened your hearts in a day of slaughter. You have condemned and put to death the righteous man; he does not resist you' (Ja 5:1-6). 
be considered and designated for whatever it is, as a sin against the will of God. These could include:

$[g]$ reed, covetousness, divided loyalties, faulty prioritization, discontentment, lack of trust, selfishness, and materialism - all of these sins need to be clearly and boldly pointed out. A heart that is not right with God cannot produce works pleasing to God. A corrupt tree produces corrupt fruit or no fruit at all. There is no shortcut to God-pleasing stewardship of giving. (Valleskey 1989:8)

The ultimate test of a Christian honesty is his or her willingness to take up the privilege of stewardship (Masters 1994:11).

In the following discussions, this article commences with the economic reality of Yehud during Malachi's day, and then highlights the intricacies of the prophet's accusations of hypocrisy concerning the tithe which Christians have traditionally taken to be the starting point or basis of stewardship, seeing it as a biblical minimum proportion which may be supplemented as the Lord prospers. In an attempt to be dispassionate, as well as careful, the article concludes by emphasising some underlying principles with regard to Christian stewardship which will serve as a reminder to Christians about their ethical responsibility. Malachi's prophetic narrative in 3:6-12 serves, not only as a warning to Yahweh's people in faith communities of the consequences of bitterness and arrogance towards him, but also as a motivation and inspiration to persist in giving even in the midst of hard economic realities.

\section{Economic reality of Yehud that underpinned Malachi's oracles}

Malachi (mal'ākhî) in the Hebrew Bible simply means 'my messenger'. The identification of the form mal'ākhî has constituted research problems and defensible positions have emerged from several scholarly debates. On the one hand, Malachi is considered to be the proper name of the writer of the oracles and on the other hand, it is seen as a name or title for the unidentified person who is responsible for the book (Hill 1998:15). It is also seen to be a product of scribal prophecy, with no single individual acting as its author (Gertz et al. 2012:521). ${ }^{2}$ Many scholars have assessed the literary features of Malachi's oracles and the discussions have centred on appropriate means of describing Malachi's approaches and/or techniques of communication with Yahweh's people (Boda 2000:299-300; Braun 1977:299; Clendenen 2004:218; Merrill 1994:380; Murray 1987:110; O’Brien 1990:63).

The division of the book's message into six smaller sections (Pierce 1984:282) with most of these segments having a threepart form namely, 'frequent use of quotations, rhetorical questions and polemical argument' (Clendenen 2004:218) - which may of itself be made up of smaller elements, that is, oracle of salvation, threat, or admonition - has given rise

2.The various controversies about the title mal'äkhî that have constituted research problems and from which defensible positions have emerged in several scholarly debates, have been dealt with in the first author's - B. Onoriode Boloje - Doctoral thesis (thesis is still in progress) to the classification of the book as comprising of disputation speeches and/or oracles (Clendenen 2004:218; Petersen 1995:29; Redditt 2000:849). Boda (2000) notes:

the interrogative mood engages the audience in a powerful way, forcing them to reflect on the message in a deeper measure than in mere pronouncements. It is used by Haggai both to bring judgement $(1: 4,9 ; 2: 12-13,19)$ and to express sympathy $(2: 3)$. (pp. 299-300)

Craig (1996:244) and Pierce (1984:277) have also developed these styles of questioning and suggest that they indicate the agreement of Haggai-Zechariah-Malachi. In Malachi, Clendenen (2004) identifies six disputation speeches:

(1) 1:2-5, (2) 1:6-2:9, (3) 2:10-16 (with the exception of vv.11-12 as a latter addition), (4) 2:17-3:5, (5) 3:6-12, and (6) 3:13-21 (English 4:3; as the last three verses of the canonical book, 4:4-6 in English are excluded as a latter addition). (p. 219)

The oracles of Malachi cannot be understood apart from at least a basic knowledge of the context in which he lived. Like the rest of the prophets, he prophesied from God, but he did so within the backdrop of the circumstances and situations of his time. Malachi addressed Judeans of a recently founded province of Judah (formally Yehud) 3 in the Persian satrapy of Eber-Nahara probably during the reign of king Darius I (522486 BCE). His audience included emigrants or deportees who had resettled in Judah and offspring of those Hebrews who had survived the Babylonian sack of Jerusalem, but were not deported to Mesopotamia. The edict of Cyrus the Great in 538 BCE serves as the historical background for the ministries of the postexilic prophets Haggai-ZechariahMalachi. Sheshbazzar, whom Cyrus appointed as governor (Ezr 5:14), barely laid the foundation of the temple. It is noted that from Cyrus's time until Darius's rise to power, the construction of the temple was not completed (Ezr 5:14; Lee 2011:163). According to Lee (2011:163), Sheshbazzar may have encountered at least a reluctance to assist on the part of the governor in Samaria, and somehow even direct hostility. The Second Temple was erected under the auspices of Persian kind Darius I, and the monies granted for the rebuilding took the form of 'tax rebates' from the Persian royal treasury (Hill 2012:526-527).

Malachi confronts a population given to religious cynicism and political scepticism. Malachi's day was one of disillusionment and gloom. The tidal waves of enthusiasm that had been created by the preaching of earlier prophets had by then crashed on the rocks of reality. The disillusionment of the postexilic Jewish community was prompted by several theological misunderstandings, including the expectations for wealth that Haggai had promised once the Second Temple

3.Stuart (1998:1253) observes that Yehud was a small province out of 120 that formed the Persian Empire. It was around $20 \times 25$ miles in size. The province was divided into at least six districts: Jericho, Mizpah, Jerusalem, Beth-Zur, Beth-Hacherem and Keilah (Hill 1998:62). Hill (1998:62) states that the 'residential population' can be estimated around 150000 based on certain texts such as Malachi 3.5. Ezra 10.2. Nehemiah around 150000 based on certain texts such as Malachi 3:5; Ezra 10:2; Nehemiah $13: 3,23$. The population 'was very small in number, and ... larger parts of the town and villages were either completely or partly destroyed, and the rest were poorly functioning' (Stern 2001:350). The important archaeological and demographic studies of Carter (1994:107-145) and Lipschits (2003:323-376, 2005:261-271) hav clarified one's understanding of the period. Lipschits (2005:261-271) estimates the population of Yehud to have been 30000 at its maximal level in the later part of the Persian period. See also Kessler (2010:309-351). 
was rebuilt ( $\mathrm{Hg} 2: 7,18-19)$, the restoration of the Davidic covenant predicted by Ezekiel (Ezk 34:13, 23-24) and the implementation of Jeremiah's 'new covenant' (Jr 31:23, 31-2) (Hill 2012:527). There was great excitement in the waning years of the 6th century BCE. The people believed, based on the words of the prophets, that a new, more prosperous and glorious, messianic age was about to manifest itself at any moment.

The Second Temple would be more glorious than the first $(\mathrm{Hg}$ 2:9). Their land would be renewed and produce abundant harvests (Ezk 34:26-30; Is 41:18-19). The land would not be able to accommodate all the people (Is 54:1-3) and the population of Jerusalem would overflow its borders (Zch 2:4). Instead of Israel being the slave, the nations of the world would serve them (Is 49:22-23) and the glory of the Lord would return to the temple (Ezk 43:1-5). However, as time went by it became more and more obvious that these prophecies would not be fulfilled in the way and the time the people had anticipated. The lives of the Israelites were restricted to Jerusalem and its immediate environment. They saw no evidence that God's glory had returned to the temple and perhaps most disappointing, there was no visible restoration of the kingdom and the promises made to David. With the events of broken dreams, lost hopes, disillusionment, sadness and resentment the people of Judah sank lower and lower morally and ethically. Israel's reaction was predictable. How could it be explained that God seemed to have abandoned and forgotten the people, the Davidic king and the priesthood he himself had chosen? Many had lost faith in the God of their fathers who, in their view, had punished them beyond reasonable measure. According to Korpel (2005) they asked:

'Why are we fasting, if you do not see it? Why do we humble ourselves, if you do not take note of it?' (Isa. 58:3). 'We await justice, but there is none, salvation, but it is far away from us' (Isa. 59:11). 'It is useless to serve God. What have we gained by keeping his charge and walking in abject awe of the Lord of Hosts?' (Mal. 3:14) She wondered what evidence could be presented to verify the claim that she was in covenant with Yahweh and that he did love her (Mal 1:2). 'Where is the God of justice?' (Mal. 2:17). (p. 138)

The pragmatic economic situations which the Judahite population met were very discouraging. As it were, when Nebuchadnezzar conquered the city, he carried away the finest of the people as captives. However, when they were gone those who remained in the land took ownership of their belongings and possessed the best of the land for themselves (Jr 39:10; Blenkinsopp 1988:60-66). The Samaritans, ${ }^{4}$ who were considered to be a miscellaneous tribe from the northern part of Israel, had come in and taken ownership of their belongings and they possessed large holdings and estates, and so many of the people had become rich and were affluent (Blenkinsopp 1988:68). The returnees could not

4.Williamson (2004.23) argues that, 'it is clear beyond a shadow of doubt that throughout the Persian period there continued to be fundamental differences of throughout the Persian period there continued to be fundamental differences of opinion within Judah concerning the attitude which should be adopted towards the descendants of the form exiles, including Ezra and Nehemiah, found it appalling to relate with the Samaritan in their religious life and communal living. They literally advocated separation from foreigners and encouraged purity of the post exilic community (Usue 2005:74). count on being welcomed with open arms and taken in by those who had been left behind, especially since economic conditions in Palestine were poor (Hg 1:6, 9-12; Zch 8:10). Wells (1987) clearly states:

They evidently taxed the Jews (Neh 5:4), a burden that lay on top of that imposed by Persia itself. Some had to borrow money just to buy food and pay taxes (Neh 5:14-15). These neighbors accused them to the central government of Persia (Ezra 4:6; $4: 7-23)$, and physically opposed their work, so that it had to be done in shifts, with half the men working and half standing guard (Neh 4:16-18) ... The situation in Jerusalem was bleak. The extensive ruins (Neh 4:10), and the inferiority of the project compared to those of the more glorious past (Ezra 3:12; Hag 2:3), diminished whatever initial enthusiasm may have existed. And the prospects for a better life seemed no better now. Small wonder that few in Babylon wanted to return to Israel. Many had grown accustomed to life there, many knew no other life, and some had prospered. (p. 40)

These hard and unwelcoming economic realities of Yehud were particularly noticeable in the prophet's emphasis on certain cultic sins (e.g. the defilement of Yahweh's table - Ml 1:7, 8, 13-14, or failing to bring the tithe - Ml 3:8-10), which were not out of disrespect for Yahweh but because the priests were acting 'on the basis of compassion or realism' particularly towards their poor Yehudites' brethren (Rogerson 1999:179). Rogerson's argument is based on the fact that Yehud experienced a change from agriculture to horticulture thus leaving the land with fewer animals to offer at the temple as sacrifice. In this regard, the references to the offering of animals that were blind, lame or sick might thus indicate a crisis in animal cultivation in which animals were scarce and flock too small. However, all this remains theoretical with respect to the background of Malachi 1:6-14 (Rogerson 1999:177-178). Whilst Rogerson admits that his point remains conjectural, Malachi 1:14 presents a strong objection to the situation. The people were so far convinced of their duty that they would bring sacrifices; they dare not wholly avoid the duty, but they brought empty oblations (even when having a suitable and acceptable [male] in their flock), mocked Yahweh, and invariably deceived themselves, by offering the worst they had.

It is also argued that 'although Darius's policy toward the provinces approached a laissez-faire posture, ... encouraging local religion, and at times local altar services', the situation became radically different when Xerxes became king in 485 BCE. Support for local religion ceased, and 'tax structures throughout the empire shifted to favor Persians and to increase the taxation upon all other ethnic and national groups'. Huge financial resources were needed to support building projects as well as military ventures in the west. 'Xerxes hedged the decline of the ethnic Persian economy by depleting the resources of the provinces'. This milieu would have placed a severe strain not only on the economy of Judah but also on the temple (Clendenen 2004:215). Whoever was the governor or administrator of Judah during this period, was either incompetent or dishonest or both. There was acute poverty due to high taxes (Neh 5:4,15) and inflation caused 
by Persian economic policies and famine (Neh 5:3), resulting in the seizure of property (Neh $5: 5,11)$ and debt slavery on a wide range (Neh 5:5, 8). Interest rate moved from $20 \%$ under Cyrus and Cambyses to $40 \%-50 \%$ by the end of the 5 th century, which may have been an additional factor to the inflation (Clendenen 2004:215). As one learns from the book of Malachi itself, there existed a progression of poor crop production and difficult seasons for Israel; drought and locust attacks devastated the land that was already largely unproductive (Hg 1:6, 10-11; Ml 3:11) (Blenkinsopp 1988:36). Crop failures were a regular occurrence, thus leaving a great many of the people to suffer poverty.

\section{Malachi's accusations of hypocrisy concerning the tithe (MI 3:6-12)}

The fifth oracle has been classified as an assertive type of 'speech act' designed to both assure and persuade the audience and/or reader (Hill 1998:291). The oracle was most probably addressed to the entire people of Judah:

Its purpose is to offer hope to postexilic Yehud by stressing Yahweh's immutability, countering the community's charge of capriciousness on God's part ... It is at this point that Malachi touches universal aspects of the human experience, coping with unfulfilled promises, shattered dreams, and hope differed. (Hill 1998:294)

Whilst the various issues covered in Malachi 3 include the eschatological visitation of Yahweh's covenant envoy (3:1), punishment of evildoers (3:5), Yahweh's timelessness (3:6) as well as an exhortation towards the repentance and return of the people to Yahweh (3:7), the central focus of this oracle concerns verses 8-10. Here, Yahweh through his prophet brought to the people's awareness an additional and different sector where their conspiracy and revolt against him was obvious, namely, the holding back of the tithes and the hypocrisy associated with them (Clendenen 2004:414). The accusations against the people with respect to their unfaithfulness and their deceitful practices in the offering of sacrifices (Ml 3:6-12) are parallel to the accusations against the priests in 1:6-2:9. These oracles 1:6-2:9 and 3:6-12, in a sense are companion pieces, in that they focus on the neglect of the cult (Tiemeyer 2006:27).

Both oracles begin with a double-assertion-questioning pattern, followed by a denunciation of unacceptable offerings, the assurance of the turnaround of fortune, and an exaltation of the name Yahweh in all the nations. Malachi 3:6-12 is addressed to the whole community, not just husbands or priests, it promises blessings whilst the second oracle knows no such promise. Probably, the main difference is that the second oracle is a warning against disobedience, showing the consequences in full, that is, curses, whilst the 5th oracle is an invitation to obedience showing the benefits, that is, blessings. Similarly, the 2nd oracle is about worship whilst that of the 5th is about temple support (Stuart 1998:1362). Thus, the delinquencies of the Judahite's population follow those of their leaders; the priests' attitude influenced the people. Since they were responsible for teaching the people and also had the authority to reject any sacrifice brought to the temple as well as correct the people, the prophet held the leaders at least partly accountable for the sins (or transgressions) of their flock. The substance of the critique in Malachi 3:6-12 is not only the people but includes the priests as well (Tiemeyer 2006:26-27).

Verse 6 is understood by scholars in different ways: the beginning of the fifth oracle (Stuart 1998:1361; Smith 1984:331), the conclusion to the previous section (Clendenen 2004:399; Pohlig 1998:151), or it serves as a link between the previous verses and the accusations which follow in 3:7 (Schuller 1996:870; Weyde 2000:324). However, Malachi 3:612 follows perfectly well the repeated pattern of Malachi's oracles. The particle $k \hat{\imath}$ is translated as a marker of emphasis, 'indeed, truly, indeed' (Pohlig 1998:151). The premise is that Yahweh has not changed. Evidently some sceptics had become weary of waiting for the promised return of Yahweh as Ezekiel and Haggai had promised. They had implied that Yahweh had changed his mind and had been unfaithful to his promise. But Yahweh says he has not changed. The first person 'ănî yhwh [I am the Lord] statement about Yahweh's unchangeable nature (lō's shānith $\hat{\imath})$ and the designation $b^{e} n \hat{e}-$ ya 'ăqōbh [children of Jacob] who have not changed, ties this verse very closely to Malachi 1:2-5 (Schuller 1996:870). This verse reveals that Yahweh, in his kindness, fairness, fidelity and commitment to Israel, has remained unchangeable. This in turn is the very reason why Israel has not been consumed (lō' khelithem). However, in their disloyalty and revolt the Judeans have not stopped to follow the rebellious ways of their ancestors.

In verse 7, the prophet reiterates the fact that Israel's covenant violation has a long history. The reason he has not returned (shûbh) in glory to them is the general accusation in 3:7 lemîmê 'ăbhōthêkhem sartem mēhuqqay welō' shemartem [From the days of your fathers you have turned aside from my statutes, and have not kept them] as in the accusation against the priests in Malachi 1:6-10. The accusation characterises the past and the present as a history of apostasy (Weyde 2000:328). Yahweh accuses the people of not keeping his ordinances, of not repenting, and of robbing him. However, the accusation is followed by an exhortation to return to Yahweh (shîbh $\hat{u}$ 'élay), and a promise - $w^{e}$ 'asshûbh $\bar{a}^{h}$ 'ălêkhem [and I will return to you], the fulfilment of which depends on their obedience. This motivating promise is followed by a response from the addressees: bamme nāshûbh [how shall we return]? Or as the New Living Testament (NLT) puts it; 'how can we return when we have never gone away?'. ${ }^{5}$ Whilst one may be tempted to think that the main issue addressed in Malachi 3:6-12 is tithing, the prevailing issue is closely associated with the issue of disrespect for the Lord:

5.The interrogative word bamme also translated as a verb phrase ([what must we do in respect of what \{sin\}]? Brown et al. (1997:553) occurs 29 times in the Hebrew Bible (HB). In Malachi's six appearances of the term, these insensitive and disorderly people ask: 'How have you loved us?' (MI 1:2); 'How have we shown contempt fo your name?" (Ml 1:6), "How have we defiled you?" (Ml 1:7); "How have we wearie you?' (MI 2:17); and now, 'How are we to return?' (MI 3:7); and 'How do we rob you?' (Ml 3:8). Yahweh's patience with his people is very amazing (Clendenen 2004:413) 
Judah is charged here with abandoning the God who had chosen and blessed them and turning away from the statutes he had given them to test their loyalty and to mark the path of life he would bless. By retaining for themselves the tithes and offerings they owed to God, the people showed their idolatrous hearts in placing themselves before God. (Clendenen 2004:429)

Rather than accepting Yahweh's offer, in verse 8, the people immediately question his words: hăyiqba' 'ädhām 'êlōhîm [will a man rob God]?

This rhetorical questioning which expects the answer 'no'

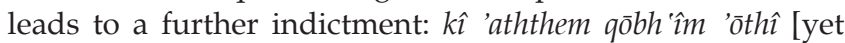
you are robbing me - Yahweh]. The verb qōbh' $i m$ from qābha' [to defraud, rob, deceive, cheat] (Brown, Diver \& Briggs 1997:867; Harris, Archer \& Waltke 1980:1981) is a Qal participle. As in previous accusations, the audience's fault is described in ongoing present terms. Similarly, the pronoun 'aththem is once more used to emphasise the identity of the guilty party (see Ml 1:12; 2:8; 3:9). Hill (1998:305) notes, the Qal participle indicates a progressive action with an existing state of being, "'you continue to rob me" or "you are still robbing $\mathrm{me}^{\prime \prime \prime}$. As soon as the people heard this indictment, and in line with the stylistic and linguistic pattern of the passage, responded once again in an attempt to know exactly how they were carrying out the robbery, that is, precisely in which way they were culpable: bamme ${ }^{h} q^{e} b h a \cdot a ̆ n u \hat{u} h \bar{a}$ [how have we robbed you]? Yahweh may have replied to them by pointing again to their hypocritical worship (Ml 1:4); their covenant violations against one another (2:10), and especially their wives (2:14); their defilement of Yahweh's sanctuary (2:11); or the corruption of personal and civil morality (3:5). Here, he however replies: hamma ăšér wehaththerûmāh [in your tithes and offerings]. The fact that both nouns: hamma ăśser wehaththerum $\bar{a}^{h}$, carry the definite article in front of them shows that the prophet has specific types of offerings in mind rather than generic offerings of all sorts; that is, the tithes and offerings recommended by Moses to Israel (Verhoef 1987:303). ${ }^{6}$ The term for tithe is ma ăšser and means 'a tenth part' or 'one tenth'. The tithe was an offering (10\% of one's earnings), to Yahweh (Pohlig 1998:157). ${ }^{7}$ If Yahweh owns the tithe and requires it to be given over to him at a particular time of the year, withholding then will be robbery (Clendenen 2004:415; Stuart 1998:1367).

But what was the specific tithe in this verse? Two types of tithes were mandated: the yearly tithe and the triennial one,

\footnotetext{
6.In Deuteronomy, Moses commanded Israel saying, "[y] ou are not allowed to eat within your gates the tithe of your grain, or new wine, or oil, or the first-born of your herd or flock, or any of your votive offerings which you vow, or your freewill your herd or flock, or any of your votive offerings which you vow, or your freewill offerings, or the contribution of your hand. But you shall eat them before the LORD your God in the place which the LORD your God will choose, you and your son and daughter, and your male and female servants, and the Levite who is within your gates; and you shall rejoice before the LORD your God in all your undertakings. $\mathrm{Be}$ careful that you do not forsake the Levites as long as you live in your land' (D 12:17-19).

7.In the Old Testament, before the Law was given, tithes are mentioned in Genesis 14:20 when Abram gave voluntarily his tithe to Melchizedek and in Genesis 28:22 when Jacob promised the tithe of everything he has to God. It was only after the Law that tithes became compulsory for every Israelite, thus acquiring a different connotation and usage than during the patriarchs' lifetime. Moses instructed the connotation and usage than during the patriarchs' lifetime. Moses instructed the
Israelites that, 'all the tithe of the land, of the seed of the land or of the fruit of the tree, is the LORD's; it is holy to the LORD' (Lv 27:30). Also, in Leviticus 27:32 it is stated, 'ejvery tenth part of herd or flock, whatever passes under the rod; the tent one shall be holy to the LORD.' After Israel's settlement in the land the people also benefited directly when they ate with the priests and Levites at the place of worship (Nm 18:21; Dt 12:4-9; 14:22-27).
}

which was set apart to be distributed to the less privileged: orphans, widows and aliens (Dt 14:22-27; 28f). This verse denotes the tithe that is set apart for the maintenance and sustenance of the temple personnel (Sweeney 2001:743). It could also refer to the 10th just as the usual tithe, assembled together in native outbuildings and set aside for the welfare of the temple personnel, that is, the Levites (Petersen 1995:215). According to Wretlind (2006:22), the idea of the tithe in verse 8 includes the whole of the Mosaic regulation concerning the tithe. Whilst one will support the view that Levites are treated here as the major beneficiaries, this view does not exclude the other usages of the tithe. For instance, in Malachi 3:5 the book points out other established beneficiaries of the tithe who are denied justice. This could be as a result of the unfaithfulness of the people in remitting their tithes. ${ }^{8}$

Again, in verse 8 it is noted that the people are defrauding Yahweh of the offerings. Here, it is uncertain as to what types of $t^{e} r \hat{u} m \bar{a}^{h}$ the text refers. The word used here $t^{e} r u \hat{u} m \bar{a}^{h}$ is translated as 'contribution, offering, heave offering, levy, tribute' (Pohlig 1998:157). ${ }^{9}$ The word was used in connection with rûm and translated as 'heave offering' which suggests that the offering was lifted up to God. A similar word that often accompanies $t^{e} r u m \bar{a}^{h}$ is the word $t^{e} n \hat{u} p h \bar{a}^{h}$, which has also been understood as an offering that is moved forward and backward (wave offering) (Clendenen 2004:416-417). Hill (1998:291) translates the paired words: hamma'ăśēr $w^{e} h a t h t^{e} r \hat{u} m \bar{a}^{h}$ as 'the tithe, the tithe tax' and points out that $t^{e} r \hat{u} m \bar{a}^{h}$ is not just a general term for offerings, since it 'extends the notion of offering to include gifts of material goods (e.g. construction supplies, garments), valuables (e.g. gold silver, precious stones), personal services, booty, etc.' (Hill 1998:306). The offerings in the text could be equated with first fruits (Feinberg 1990:263), or the tax of tithe or simply tithe of the tithe dedicated to the maintenance and sustenance of the temple personnel as well as temple ministries (Petersen 1995:216). In this regard, the tithes, then, were treated as specific kind of $t^{e} r u m \bar{a}^{h}$. Probably the allusion to the $t^{e} r u m \bar{a}^{h}$ signifies that not only were the people failing to provide the Levites with the tithes, but also the Levites were failing to tithe in order to sustain the priests. One can conclude then that Yahweh's clarification to the people in the book of Malachi in all probability implies that they were withholding the offerings that were his, particularly the tithes, which were intended to be given to sustain temple personnel as well as the temple ministries.

What could have led to this unawareness on the part of the people? Could such have been caused by the lack of adequate instruction in the Law? What could have made the priests not want to instruct the people of Yehud to give their tithe? Above all, the priests had access to the Law and the authority

8.It is noted, "the relevant stipulations of the Law were enthusiastically carried out only fitfully, and that often tithing almost completely lapsed ... Nehemiah instituted a full program of tithing among the returned Jews in Jerusalem, only to find it in ruins on his second visit' (Pohlig 1998:158).

9.The term $t^{e} r u m \bar{a}^{h}$ is well known to the Old Testament, (esp. Ex 29:27-28; Lv 7:14 9.The term $t^{e}$ rum $\bar{a}^{n}$ is well known to the Old Testament, (esp. Ex 29:27-28; Lv 7:14, a broad term (Lv 22:2, 3, 12, 15; Nm 5:9; 15:17-21; 18:8-20) to a more specific a broad term (Lv 22:2, $3,12,15 ; \mathrm{Nm} 5: 9 ; 15: 17-21 ; 18: 8-20)$ to a more specific
offerings set aside for the priests (Ex 25:1-7; 29:27, 28; 30:11-16; 35:4-36:11; LV 7:14, 32, 34; 10:12-15; Nm 6:20; 31:25-54; Dt 12:6-17; 2 Chr 31:12; Ezr 8:25). 
to teach the laymen about cultic matters and they were the ones who benefited most economically from the tithe. It seems that the reason why the people were not tithing is not so much because they were not told to do so by the priests, but because of their contempt for Yahweh. The 'people's attitude toward and use of their possessions was' only a clear 'indication of the health of their relationship' namely with Yahweh (Clendenen 2004:414). In verse 9, before the accusation is repeated, it is immediately stated: bamme' $\bar{e} r \bar{a}^{h}$ 'aththem ne' ârîm [you are cursed with a curse]. The use of the noun $m^{e}{ }^{\prime} \bar{e} r \bar{a}^{h}$ [curse] (Brown et al. 1997:76) and the Niphal participle ne' 'ârim of 'ârar [cursed, inflicted with a curse] which expresses an action begun in the past but with continuing effect in the present suggests that this expression refers to a present condition; a curse is in force (Pohlig 1998:158). The relationship between the two clauses in verse 9, which are linked by $w^{e}$, appear obscure; it is either that the addresses's robbing of Yahweh is presented as the reason why the curse is in effect, or the meaning is: 'You are cursed with a curse, but you continue to rob me' (Weyde 2000:326).

Malachi 3:11 provides the hints that the curse might have been related to a lack of produce from the land - 'it shall not destroy the fruits of the ground for you, nor will the vine of your field be barren for you'. The socio-economic problems in the post-exilic period of the 5th century BCE have already been noted earlier, namely, that the returned exiles grappled with many difficulties. There existed a progression of poor crop production and difficult seasons for Israel; drought and locust attacks devastated the land that was already largely unproductive, thus leading to poverty and years of internal conflict and struggle (cf. Hg 1:6, 10-11). In line with the curses described in Deuteronomy (Dt 28:20-21,38, 42), it is observed that the components of this curse included a devastated and barren land (Sweeney 2001:744). In the second clarification of the accusation the addresses are identified as: haghghôy kullô [the whole nation of you]. The noun $k \bar{o} l$ denotes a totality of something (Brown et al. 1997:481). It signifies completeness and it is used here substantively as 'all of it' that is, the entire nation was culpable before Yahweh and thus was in a perilous situation (Clendenen 2004:414; Mounce 2006:12). Although, in the Old Testament (OT) Israel is typically referred to as gôy in a derogatory sense ( $\mathrm{Zph} 2: 1$ ), the term is generally reserved for the heathen nations. ${ }^{10}$ Malachi's use of the term as a reference to Israel may suggest that, according to the scribes of the book, Yahweh in his anger is comparing Israel to a pagan nation, thus rejecting their attitude (Clendenen 2004:420; Pohlig 1998:158; Stuart 1998:1369).

Verse 10 gives an answer to the situation which if they accept will lead them to experience the favour of Yahweh again and again. As observed by Stuart (1998:1369), ${ }^{11}$ this verse is a combination of imperatives and promises. It starts with

10.haghghôy is repeatedly used for Israel in the Old Testament in a positive way (Gn 15:14;17:20; 18:18; 21:13, 18; 46:3; Ex 19:6; 32:10; Nm 14:12; Dt 9:14; 26:5; Jos $3: 17 ; 5: 6-8 ;$ is $9: 3 ; 26: 2,15)$.

11.Stuart makes six observations in connection with this verse: (1) It does not constitute a promise that individual believers become prosperous if they tithe; (2) Partial tithing is a contradiction in terms; (3) God here subjects himself to testing, but not of the sort prohibited elsewhere as ungodly; (4) Malachi was not a narrow but not of the sort prohibited elsewhere as ungodly; (4) Malachi was not a narrow
ritualist who valued preservation of the cultus over moral living; (5) The actual kind ritualist who valued preservation of the cultus over moral living; (5) The actual kind
of blessing promised is a combination of abundant rain and freedom from crop pests, used as a synecdoche for restoration blessings of all sorts; and (6) There is an eschatological overtone to the promise. commands and ends with conditional imperfects describing what can happen if the addressees obeyed the command. The Hiphil imperative hābĥे'û means 'bring' (Brown et al. 1997:97) and is used in similar ways with respect to the tithe (Dt 12:6, 11; Am 4:4; Neh 10:38; 2 Chr 31:5, 6, 12). The first important matter of concern in this verse is the precise meaning of the idea: 'eth-kol-hamma'ăśêr [the whole tithe]. Were the people only bringing a portion of their tithe and holding back the rest, or does the idea refer to a specific kind of tithe already mentioned?

The idea of the passage brings to mind references to tithing: ' $[A] 11$ the tithe of the land' (Lv 27:30) and 'the entire tithe in Israel' (Nm 18:21). Specifying the 'the whole tithe' indicates that many were either bringing a portion of their tithe or were bringing nothing at all. This as well echoes the guilt of the whole nation in verse 9 (Clendenen 2004:420). Since the whole tithing structure appears to have been disregarded by those who returned from the exiles and succeeding generations, as can be deduced from the efforts of both Nehemiah (Neh 10:32-39; 13:10-14) and Malachi toward its restoration, it appears as if in this present context the prophet is attempting to get the whole system started all over again. This time however, with the support for the temple personnel as a priority in the light of their significant role in its (temple) cultic life of both worship and sacrifices. Thus the major emphasis is that, even in their unfavourable and undesired situation, the people are motivated to dedicate themselves to the fulfilment of their covenant responsibilities with respect to the tithe. They are to bring the whole of their tithe and not holding back any portion.

The expression bêth hā'ôtsār refers to the public storehouse, for the goods tithed by the people for the priests, Levites and the less privileged of the nation (cf. Neh 13:10-13). Nehemiah called the storehouse 'a great chamber' (Neh 13:5; Pohlig 1998:161). A literal Hebrew meaning of 'house of supplies' has been suggested (Verhoef 1987:305). There are several passages that give one a clearer and broader picture of what the temple storehouse looked like. Hill (1998) notes:

depending on the kinds of goods stockpiled, the 'ôtsār may have constituted a 'wardrobe' (Jer. 38:11) or an 'arsenal' (Jer. 50:25), an official 'treasury' (cf. 1 Kgs. 14:26; 15:18) or simply some type of 'warehouse' or 'storehouse' (Joe. 1:17). (p. 310)

These rooms are identified to be 'additional halls that were located around the main temple' (Hill 1998:310). A difference between 'storehouses' and 'chambers' has also been established. On the one hand, the 'storehouses' are considered to be local accommodations reserved for the 'general' tithe, and on the other hand, the 'chambers' were quarters located within the complex of the temple that were used for the purpose of storing the 'tithe tax' that was taken along by the priests to Jerusalem (Petersen 1995:216).

The primary emphasis of the verse then is on the motif of bearing the tithes to the storehouse; namely, wîh tereph [so that there may be food in my house]. This meaning of the term tereph is 'food, provision, consumption, meat, 
nourishment' (Pohlig 1998:161) or 'fresh food' (Petersen 1995:217). The parallelism of bêth hā'ôtsār with bebhêth my house] in this verse allows the deduction that the temple complex could indeed store a large amount of contributions. Yahweh then makes an offer: $\hat{u} b h^{e} h \bar{a} n \hat{u} n \hat{\imath} n \bar{a}$ ' bāzō'th [test me now in this]. O'Brien (1990:75) puts it thus 'if you will honour what is due me, I promise to make you prosper'. The Qal imperative bhe hānûn̂ि from bāhan [to test, prove try] (Brown et al. 1997:103) gives the explicit idea that these words constitute a challenge (Pohlig 1998:161). The idea of testing Yahweh in the text appears to be very uncommon and has an undesirable meaning in certain passages of scripture. For instance in Exodus 17 one reads:

Therefore the people quarrelled with Moses and said, 'give us water that we may drink.' And Moses said to them, 'Why do you quarrel with me? Why do you test the LORD?'. (v. 2; cf. Nm 14:22)

In several occurrences, the word is used to mean Yahweh testing man (Clendenen 2004:422). However, according to Mounce (2006:718) the term also carries the idea of trying to describe something appearing to be real, 'especially in the context of a covenant relationship'. The result of the test is made very clear; Yahweh will accomplish what he had declared to do. The promise approximates the language of the covenant blessings. ${ }^{12}$ Profound fruitfulness and felicitations lie in wait for the nation once the people come back to Yahweh. It is the nation as a whole that will reap the blessings. The point of emphasis however is that, 'the promise is, however, corporate, not individual, as are virtually all Old Covenant promises of abundance' (Stuart 1998:1369).

Yahweh's response to the people's dedicated loyalty is found in the expression: 'im-lō' 'ephtah lākhem 'ēth 'ărubhbhôth hashshāmayim wahărî̄ōhî lākhem berākh $\bar{a}^{h}$ 'adh-blî̀-dhāy [if I will not open the floodgates of heaven and pour out for you a blessing until it overflows]. The phrase 'ărubhbhôth hashshāmayim [floodgates of heaven], is basically taken to be an indication of rain, the key to agricultural prosperity at almost all times and places in world history (Clendenen 2004:424; Stuart 1998:1370). For the rain to descend, heaven's floodgates ('ărubhbhôth hashshāmayim) had to be opened (cf. Gn. 7:11-12). Their closure was threatened by Yahweh as punishment for disobedience to him (Dt 11:16f.) (Pohlig 1998:164). The promise of rain indicates that Malachi and his contemporaries may have been experiencing a want of it, which invariably is an indication of a covenant curse (Lv 26:19; Dt 28:22-24) (Stuart 1998:1371). The Hebrew verb rîq translated 'pour out' refers to being empty. Here it is understood basically to mean the abundant blessings that would answer the people's submission to Yahweh (Clendenen 2004:425). The critical word day [sufficiency,

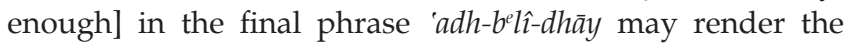
whole phrase to mean, 'I will pour out a blessing until there is no sufficiency, i.e., until my abundance can be exhausted, or as this can never be, forever' (Brown et al. 1997:191).

12.In Deuteronomy $28: 11-12$, God promises to bless the faithful by "opening the heavens' and sending abundant blessing. Here in Malachi, the Lord promises to
rebuke the devourer, and the fruit and the vine will thrive. Moreover, all nations rebuke the devourer, and the fruit and the vine will thrive. Mor
will affirm the blessedness of the land (O'Brien 1990:75-76).
Abundant rain is not the sum total of what is needed for agricultural productivity. Absence of crop pests and crop diseases are needed as well. Yahweh then promises further to 'reproach the destroyer' and restrain it from wreaking havoc with their fruit (perî) and vine (gephen) (Ml 3:11). The verb $g \bar{a}{ }^{\prime} a r$ [to rebuke, reproach, forbid, banish to retrain] (Brown et al. 1997:172) is part of the vocabulary of cursing in the OT. It denotes the retraining of something, in other words, that it will not work as it should or that it will be destroyed (see 2 Sm 22:16; Is 50:2; 51:20). According to Keil and Delitzsch (2002:660), the devourer probably refers to locusts which could destroy any crops, and then leaving barren the land in the process. Mounce (2006:916) observes that the verb gā'ar could also be interpreted as reprimand or prevention, with special allusion to insects. As he had been against them in the past for their wickedness (Lv 26:17-25; Dt 11:17; 28:20), so Yahweh promised to be for them: in the opening of the floodgates of heaven, in pouring out of blessing and in rebuking whatever was destroying their crops, to protect their agricultural harvest from destruction and their vines from unfruitfulness (cf. Jl 2:19, 23-25; Zch 8:13-15; Ml 4:2; Clendenen 2004:426).

The restoration of blessings upon Israel is made manifest in verse Malachi 12: Israel will be so impressive that all nations of the world (kol-haghghôyim) will call her blessed and as a nation Israel will be, to the general recognition of all, delightful ('erets hêphets) (Stuart 1998:1371). Whilst the expression 'ishsherû [call you blessed] could be translated as 'will congratulate you' (Deutsch 1987:106), the 'erets hêphets indicates that the land will be an object of pleasure, both to the nations and to Yahweh who created, graciously bequeathed and beautified it (Clendenen 2004:428). Thus the people will no longer be able to say 'God delights in the wicked' (Ml 2:17), for it will be obvious that they, the righteous, are the 'erets hẹphets [land of delight].

\section{Ethical principles for Christian stewardship}

The economic angle of the OT ethics focuses on the land that was considered 'not just a neutral stage where the drama unfolds' but 'a fundamentally theological entity' (Wright 1983a:50). The land was an important category as well as a defining theme in OT tradition (Brueggemann 2002b:120). Although Yahweh graciously gave the land to Israel as their heritage, they were to live in it in total reliance on him: 'The land is mine and you are resident aliens and tenants with me' (Lv 25:23). Thus the manner in which the land was considered and treated by Israel along with its yield was a key feature of their assignments under Yahweh's covenant. Brueggemann (2002a) notes:

The gift of land provides secured people with dangerous alternatives ... Israel knows very early that the need to rework identity in the land can lead to a new identity that perverts the land, distorts Yahweh, and destroy[s] Israel ... land, source of life ... invites Israel to enter life apart from [the] covenant ... Israel does not have many resources with which to resist the temptation. (p. 50) 
The land along with all its produce was to serve as a constant reminder and declaration of Israel's reliance and Yahweh's trustworthiness, as evidence of the relationship between God and Israel. This historical land-gift tradition engendered individual property rights in Israel and the follow-up to the Naboth incident opens up the prophets' preoccupation with economic exploitation (Wright 1983b:51-55). The sterility of the land in Malachi, presumes that although the reconstruction of the temple has been achieved, once again, the people are attempting to defraud Yahweh by keeping back their contributions and tithes as well as the appropriate sacrifices. Unless they have a change of attitude and return to Yahweh, Yahweh will not bring back the fortunes and abundant fruitfulness of the land for them to experience and enjoy. The prophet then assures the return of rain and the elimination of the destroyer as soon as the people return to Yahweh and with their full tithe to the temple (Ml 3:10-11). Alden (1985:721) observes that, since 'he was dealing with an agrarian society, the "blessings" had to do with crops and the like'. The anticipated blessing is treble: (1) Yahweh will open the windows of heaven; (2) he will restrain the devourer from destroying their crops; and (3) the vines will not fail to be fruitful. The restoration of abundant fruitfulness after chastisement (cf. Am 9:13-14; J1 2:12-27) is an obvious indication that their covenant affiliation with Yahweh has once again, been re-established (Nogalski 2007:129-130).

One must acknowledge, at this point, though space will not allow for an elaborate discussion, the fact that there are issues that limit the ways in which the text (Ml 3:6-12) can be made useful to a contemporary Christian community of faith. The limitations involved are both theological and practical. Theologically, one sees a clear argument against the situation of subjecting Christians to the requirements to the Mosaic regulations, ${ }^{13}$ especially those regulations that are directly connected to the sacrificial system of the temple. For example, if a Christian is a cattle farmer, is he or she obligated to come to Church on Sunday with every 10th animal as his or her tithe? With respect to the practical dimension, the tithe was basically limited to farm produce, there were restrictions as to its recipients, and its execution was subjected to certain and changing regulations. Kostenberger and Croteau (2006b) in their opinion note:

it may be that this passage in Malachi should be understood as a one-time, special act on God's part to renew the fires of faith in an age of skepticism and indifference. If so, then this is not an open-ended promise to bless in a material way anyone and everyone who tithes his possessions. (p. 70)

13.As has been noted earlier, Moses instructed the Israelites that, 'all the tithe of the land, of the seed of the land or of the fruit of the tree, is the LORD's; it is holy to the LORD' (Lv 27:30). Also, in Leviticus 27:32 it is stated, '[e]very tenth part of herd or flock, whatever passes under the rod; the tenth one shall be holy to the LORD.' Verse 31 however states that the tithe of the grain may be redeemed by the owner, at a price higher than its market value. In Numbers, there is the specification concerning the harvest's tithe and that of the animal which should be given to the officiating personnel, that is, the Levites (Nm 18:21-32). After Israel's settlement in the land the people also benefited directly when they ate with the priests and Levites at the place of worship (Nm 18:21; Dt 12:4-9, 5-18;14:22-27). In these passages, it is also specified that the 10 th part was to be gathered into In these passages, it is also specified that the 10th part was to be gathered into an approved sanctuary every year for a festive ceremony. However, if there was long distance to the designated sanctuary, a monetary exchange was to be made for the tithe and such exchanged money would be used to buy anything that was important for the festive ceremony as soon as the offerer arrives (cf. Dt 14:22-27). This distinctive kind of tithe was to be preserved in one's native town, while the foreigner, the orphans and the bereaved, including the Levites all taking part in the distribution of the goods as much as required (cf. Dt 26:12-15).
To them:

the present passage, at the very least, does not conclusively settle the question of whether or not tithing should continue into the new covenant period. The question of whether the command to tithe is applicable also for the new covenant era cannot be decided. (Kostenberger \& Croteau 2006b:70)

In considering the practicability of Malachi 3:6-12 in a contemporary Christian context, Verhoef (1987) notes that:

the continuity consists in the principle of giving, in the continued obligation to be worthy stewards of our possessions, but the discontinuity in the manner in which we fulfill our obligations. (p. 311)

With respect to the regulation of the OT, one can state that whilst the specific legislations do not all apply, the principles involved certainly do (Alcorn 2003:181). Blomberg (1999:80) notes that one must be able to recognise and appreciate the unique importance of the relationship that existed between the contributions in terms of offerings and tithes and the cult of the temple. In the absence of a similar centre for sacrifices today, it becomes very difficult for one to simply attempt to transfer all the various rules for giving in the OT to church giving principles in the New Testament (NT) category. Christian communities as well as their leaders may freely apply the regulations to fit the prevailing context by way of protecting the intent of the regulations and adjusting the application (Goldingay 2003:739-740). What ethical challenge does reflection on Malachi's prophetic dialogue on the economic angle present Yahweh's people with - their attitude toward and use of their possessions? The following underlying principles and reflections represent ethical ideals and practical moral demands that may be appropriately applied to Christians, that is, Yahweh's people living in faith communities.

\section{Acknowledgment of Yahweh's ownership and motivation for his honour}

In the OT, the economic angle concerns Israel's attitude and treatment of their material possessions. This to a large extent is what constitutes the concern of Malachi in this last disputation (Mt 3:24 [3:7-4:6]) (Clendenen 2004:236). The central emphasis of the message of the book was to once again, ignite the flames of hope and confidence in the hearts and minds of the depressed Judaeans. The reality that these people were holding back their required contributions was an indication of a greater disloyalty of the entire nation. Thus, it might be said that the essence of this aspect of the oracle is to invite them to return to Yahweh in repentance, which in the book of Malachi then applies to the major concern of tithing. Irrespective of their disloyalty and unfaithfulness, Yahweh still loved them and unwearyingly waited for their return:

Yahweh waits to be gracious unto his people; but the exercise of his grace is conditioned upon a proper attitude of mind and heart on the part of the would-be recipients. (Kostenberger \& Croteau 2006b:68)

The focus on the tithe in the book of Malachi particularly in the fifth disputation oracle (3:6-12) is closely associated 
with the issue of disrespect for the Lord. The people's perspective with respect to and use of their wealth and/ or personal effects was simply a symptom of the viability of their covenant relationship with Yahweh (Clendenen 2004:414). It is believed that an individual's opinion toward personal effects and belongings is a kind of measuring device that regulates the well-being of his or her relationship with Yahweh and with his or her neighbour (cf. Wright 1983a:5962). Thus 'failure to honour God in the material realm cannot be compensated for by religiosity in the spiritual realm' (Wright 1983a:53). Yahweh casts himself in the role of the land owner and the Israelites as the dependent tenants, and as Wright (1983a) observes:

[h] e was a God worthy of obedience; his response to human behavior would be consistent and dependable, not a matter of arbitrary whim. He could be pleased, but not humoured. (p. 53)

The divine ownership generated a wide range of responsibilities. Wright (1983b) notes:

Responsibility to God for the land which included such things as tithes and first-fruits of harvest, other harvest laws, and the sabbatical legislation. ... Responsibility to the family included the fundamental law of inalienability ... redemption procedures, inheritance rules and levirate marriage. Responsibility towards one's neighbours included a host of civil laws and charitable exhortations concerning ... respect for integrity of boundaries, generosity ..., fair treatment of employees and, indeed, of working animals. (p. 58-59)

The basic and essential principle of the tithe was simply an acknowledgement on the part of the Israelites that all their belongings evidently and eventually belonged to Yahweh. This kind of recognition of Yahweh's ownership and/or proprietorship was to be followed through the giving of the tithe, in the sense that such submission represented the dedication of all (Davis 1987:86). The reservation of a certain percentage of their income or produce to be consecrated unto Yahweh indicated his ultimate ownership of all that they owned as a people, in addition to Yahweh's provision in granting them the land to farm. Thus, the unproductiveness of the produce of the land served as a direct indication of their inability to surrender the specified contributions, namely the tithes and offerings. Yahweh's proprietorship is exercised in his gracious bestowal to his people, of the land of Canaan:

And the LORD appeared to Abram and said, 'To your descendants I will give this land.' So he built an altar there to the LORD who had appeared to him. (Gn 12:7)

It is also manifested in his ability to apportion a 10th to temple personnel, that is, the Levites in Israel:

And to the sons of Levi, behold, I have given the entire tithe in Israel for an inheritance, in return for their service which they perform, the service of the tent of meeting. (Nm 18:21)

Yahweh's ability to pronounce blessings or to curse the produce of the ground is shown in Malachi (3:10-11). The submission of the 10th in this manner was simply an indication of reverence that acknowledges Yahweh as the sovereign LORD over the earth and the only supplier and sustainer of Israel (Hill 1998:305). Positively, then, the book of Malachi's ethics is a powerful and robust notice that motivation for Christian stewardship should emanate from, first and foremost, an acknowledgement of Yahweh's ownership of all the Christian's resources and a high regard for his honour. Thus, having a disposition towards wealth and/or personal effects that incorporates this understanding that all evidently and eventually belonged to Yahweh, is very important.

\section{Motivation for total Christian stewardship}

Faithful Christian stewardship involves recognition and appreciation of the sovereignty of God over his creation, the dynamic faithful administration of one's vocation or calling, and a voluntary giving of alms on a godly basis:

It includes everything that a Christian does in grateful response to God's grace and mercy. Stewardship fits in with such activities as worship, prayer, charity and evangelism. Stewardship is one of the many ways by which a Christian seeks to love God with all his heart and soul and mind and to love his neighbor as himself. (Valleskey 1989:1)

One can say then that the basis of this functional and viable association is love. The love of God for humanity compelled him to giving himself and the Christian response to this love is in following his example. Thus, open-handed and enthusiastic giving can only happen within the context of genuine love (Kostenberger \& Croteau 2006a:250).

The theme of Yahweh's faithfulness and generosity in Malachi 3:6-12 has implications for contemporary Christians. Judah manifested their rebellion in their neglect and/or refusal to give the tithe (an addition to other violations). This neglect and/or refusal obviously had severe effects on the people and nation; since the sacrificial system of worship in the temple was related to and dependent largely upon the contributions (tithes and offerings) to support those who officiated there. The prophet had to remind the people by calling them back to the ethical requirements of their covenant obligations, namely, that the maintenance and sustenance of the temple personnel and temple ministry was their ethical duty. Malachi's prophetic narrative in 3:6-12 serves, not only as a warning to Yahweh's people in faith communities of the consequences of bitterness and arrogance towards him, but also as an encouragement and strong motivation and inspiration to persist in giving even in the midst of hard economic realities. The most reasonable deduction that one can make here is that the ministries of the Christian church should be funded by the contributions of her members. There is nothing that can be more shameful than a church which goes about organising fund-raising events, lotteries and the like in order to carry on the work of the ministry. Such approaches bring shame to God's reputation and certainly can never be pleasing to and invariably honour him (Davis 1987:93).

Since the giving of an individual is merely a noticeable means of demonstrating his or her love for God, members of 
faith communities are expected to give generously in reply to the generosity and grace of Yahweh, without being forced (Marshall 2004:287). The Christian stewardship of material resources does not concern itself only with what is given to the individual members of the church, but takes into account all the needs, privileges and assignments that Yahweh sets before the individual Christian. Thus, total Christian stewardship requires critical examination and evaluation of all needs, privileges and assignments, and taking note of their relative significance and necessity. It is in this light that the Christian who is a responsible steward will make proper decisions in the fear of Yahweh and inspired by his grace. This critical assessment and evaluation guides him or her to determine priorities in the allocation of scarce and available resources. Total Christian stewardship consists of serving one another by sharing our scarce and limited resources with each other as God has graciously bestowed them on us.

\section{Conclusion}

This article begins with a survey of the economic reality of Yehud during Malachi's day, and then highlights the intricacies of the prophet's accusations of hypocrisy concerning the tithe. In an attempt to be dispassionate as well as careful, the article concludes by emphasising some underlying principles with regard to Christian stewardship which will serve as a reminder to Christians about their ethical responsibility. These underlying principles and reflections represent ethical ideals and practical moral demands that may be appropriately applied to Christians, that is, Yahweh's people living in faith communities. The focus on the tithe in the book of Malachi particularly in the fifth disputation oracle (3:6-12) is closely associated with the issue of disrespect for the Lord. The people's perspective with respect to and use of their wealth and/or personal effects was simply a symptom of the viability of their covenant relationship with Yahweh.

Indeed, Malachi's ethical contribution with respect to the tithe in Malachi 3:6-12 which is based on the theme of Yahweh's faithfulness and generosity has inherent implications for contemporary Christians in faith communities. The Judeans in Malachi's day manifested their rebellion in their neglect and/or refusal to give the tithe (in addition to other violations). This neglect and/or refusal obviously had severe effects on the people and the nation; since the sacrificial system of worship in the temple was related to and dependent largely on the contributions (tithes and offerings) to support those who officiated there. The prophet had to remind the people by calling them back to the ethical requirements of their covenant obligations, namely, that the maintenance and sustenance of the temple personnel and temple ministry was their ethical duty. Malachi's challenge in this regard, makes a powerful and robust ethical appeal to Christians in faith communities that motivation for Christian stewardship should emanate from an acknowledgement of Yahweh's ownership of all the Christian's resources and a high regard for his honour. Whilst this challenge does not only serve as a warning to Yahweh's people in faith communities of the consequences of bitterness and arrogance towards him, it is also an encouragement and strong motivation to persist in giving even in the midst of hard economic realities.

\section{Acknowledgements Competing interests}

The authors declare that they have no financial or personal relationship(s) that may have inappropriately influenced them in writing this article.

\section{Authors' contributions}

The article is based on research conducted by B.O.B. (University of Pretoria) for his PhD thesis. A.G. (University of Pretoria), co-author of the article, acted as supervisor for the thesis.

\section{References}

Alcorn, R., 2003, Money, possessions, and eternity, rev. edn., Tyndale House, Caro Stream.

Alden, R.L., 1985, 'Malachi': The expositor's Bible commentary, vol. 7, F.E. Gaebelein (ed.), Zondervan, Grand Rapids.

Blenkinsopp, J., 1988, Ezra-Nehemiah: A commentary, John Knox Press, Westminster.

Blomberg, C.L., 1999, Neither poverty nor riches: A biblical theology of possessions, Inter-Varsity Press, Downers Grove.

Boda, M.J., 2000, 'Haggai: Master rhetorician', Tyndale Bulletin 51(2), 295-304

Braun, R., 1977, 'Malachi: A catechism for times of disappointment', Currents in Theology and Mission 4(5), 297-303.

Brown, F., Diver, R.S. \& Briggs, C.A. (eds.), 1997, Hebrew and English lexicon of the Old Testament $(B D B)$, Hendrickson Publishers, Peabody

Brueggemann, W., 2002a, The land: Place as gift, promise, challenge in biblical faith, 2nd edn., Fortress Press, Minneapolis.

Brueggemann, W., 2002b, Reverberations of faith: A theological handbook of Old Testament themes, Westminster John Knox Press, Louisville.

Carter, C., 1994, 'The province of Yehud in the post-exilic period: Surrounding site distribution and demography', in C.E. Tamara \& R. H. Kent (eds.), Second temple studies 2: Temple and community in the Persian period, pp. 107-145, JSOT Press, Sheffield. (Journal for the Study of Old Testament, suppl. ser. 175).

Clendenen, E.R., 2004, 'Malachi', in E.R. Clendenen \& R.A. Taylor (eds.), Haggai, Malachi, pp. 203-464, Broadman and Holman Publishers, Nashville. (New Malachi, pp. 203-464, Broadn
American Commentary, 21A).

Craig, K.M. Jr., 1996, 'Interrogatives in Haggai-Zechariah: A literary thread?', in P.R. House \& J.W. Watts (eds.), Forming prophetic literature: Essays on Isaiah and the Twelve in honor of John D.W. Watts, pp. 224-244, Sheffield Academic Press, Sheffield.

Davis, G.B., 1987, 'Are Christians supposed to tithe?', Criswell Theological Review 2(1), 85-97.

Deutsch, R.R., 1987, A promise of hope-a call to obedience: A commentary on the books of Joel and Malachi, ITC, Wm. B. Eerdmans, Grand Rapids.

Feinberg, C.L., 1990, The minor prophets, Moody Press, Chicago.

Gertz, J.C., Berlejung, A., Schmid, K. \& Witte, M., 2012, T\&T Clark handbook on the Old Testament: An introduction to the literature, religion and history of the Old Testament, T\&T Clark International, New York.

Goldingay, J., 2003, Old Testament theology: Israel's Gospel, vol. 1, IVP Academic, Downers Grove.

Harris, R.L., Archer, G.L. \& Waltke, B.K. (eds.), 1980, Theological wordbook of the Old Testament Moody Press, Chicago. (TWOT, 2 vols.).

Hill, A.E., 1998, Malachi: A new translation with introduction and commentary, Doubleday, New York. (Anchor Bible, 25D).

Hill, A.E., 2012, 'Malachi, Book of', Dictionary of the Old Testament prophets, in M.J. Boda \& G. McConville (eds.), Inter-Varsity Press, Downers Grove, pp. 525-533.

Keil, C.F. \& Delitzsch, F., 2002, Commentary on the Old Testament, vol. 4, Hendrickson Publishers, Peabody.

Kessler, J., 2010, "Images of exile: Representations of the "exile" and "empty land" in sixth to fourth Century BCE Yehudite literature', in E. Ben Zvi \& C. Levin (eds.), The concept of exile in Ancient Israel and its historical contexts, pp. 309-351, Walter de Gruyter, Berlin/New York.

Korpel, M.C.A., 2005, 'Disillusion among Jews in the postexilic period', in R.P. Gordon $\&$ J.C. de Moor (eds.), The Old Testament in its world, pp. 135-157, Brill, Leiden. (Oudtestamentische Studien 52).

Kostenberger, A.J. \& Croteau, D.A., 2006a, 'Reconstructing a biblical model for giving: A discussion of relevant systematic issues and New Testament principles', Bulletin for Biblical Research 16(2), 237-260. 
Kostenberger, A.J., \& Croteau, D.A., 2006b, 'Will a man rob God? (Malachi 3:8): A study of tithing in the Old and New Testaments', Bulletin for Biblical Research 16(1), 53-77.

Lee, K-J., 2011, The authority and authorization of the Torah in the Persian period, Peeters, Leuven. (Contributions to Biblical Exegesis and Theology, 64).

Lipschits, O., 2003, 'Demographic changes in Judah between the seventh and fifth centuries B.C.E.', in O. Lipschits \& J. Blenkinsopp (eds.), Judah and the Judeans in the Neo-Babylonian Period, pp. 323-376, Eisenbranus, Winona Lake.

Lipschits, O., 2005, The fall and rise of Jerusalem: Judah under Babylonian rule, Eisenbranus, Winona Lake.

Marshall, I.H., 2004, New Testament Theology: Many witnesses, one Gospel, InterVarsity Press, Downers Grove.

Masters, P., 1994, Tithing: The privilege of Christian stewardship, Sword \& Trowel, London.

Merrill, E.H., 1994, Haggai, Zechariah and Malachi: An exegetical commentary, Moody Press, Chicago.

Mounce, W.D., 2006, Mounce's complete expository dictionary of Old and New Testament words, Zondervan, Grand Rapids.

Murray, D.F., 1987, 'The rhetoric of disputation: Re-examination of a prophetic genre', Journal for the Study of Old Testament 12(38), 95-121. http://dx.doi. org/10.1177/030908928701203808

Nogalski, J.D., 2007, 'Recurring themes in the book of the twelve: Creating points of contact for a theological reading', Interpretation 61(2), 125-136. http://dx.doi. org/10.1177/002096430706100202

O'Brien, J.M., 1990, Priest and Levite in Malachi, Scholars, Atlanta. (Society of Biblical Literature Dissertation Series, 121)

Petersen, D.L., 1995, Zechariah 9-14 and Malachi, SCM Press Ltd., London. (Old Testament Library).

Pierce, R.W., 1984, 'Literary connectors and a Haggai/Zechariah/Malachi corpus', Journal of the Evangelical Theological Society 27, 277-289.

Pohlig, J.N., 1998, An exegetical summary of Malachi, Summer Institute of Linguistics Inc., Dallas.

Redditt, P.L., 2000, 'Book of Malachi', in W. Elwell (ed.), Eerdmans dictionary of the Bible, Baker, Grand Rapids, vol. 3, pp. 848-849.

Rogerson, J.W., 1999, 'The social background of the book of Malachi', in A. Gelston, C.T.R. Hayward, P.J. Harland \& R. Hayward (eds.), New heaven and new earthprophecy and the millennium: essays in honour of Anthony Gelston, pp. 171-179, Brill, Leiden. (Vetus Testamentum supl., 77).
Schuller, E.M., 1996, 'The Book of Malachi', in L.E. Keck \& D, Peterson (eds.), The new interpreter's Bible, pp. 843-877, Abingdon Press, Nashville.

Stern, E., 2001, Archaeology of the land of the Bible: The Assyrian, Babylonian and Persian Periods (732-332 B.C.E.), vol. 2, Doubleday, New York.

Stuart, D., 1998, s.v. 'Malachi', in T.E. McComiskey (ed.), The minor Prophets: An exegetical and expository commentary, vol. 3, pp. 1245-1396, Baker Books, Grand Rapids.

Sweeney, M.A., 2001, The twelve prophets: Micah Nahum, Zephaniah, Haggai, Zechariah, Malachi vol. 2, The Liturgical Press, Collegeville.

Tiemeyer, L.S., 2006, Priestly rites and prophetic rage: Post-exilic prophetic critique of the priesthood, Mohr Siebeck, Tubingen. (Forschungen zum Alten Testament, 19).

Usue, E.O., 2005, 'The theological perspectives on the concept of "Yahweh's people" in Ezra and Nehemiah during the early post-exilic period (539-350 BC)', PhD thesis, Department Old Testament Studies, University of Pretoria.

Valleskey, D.J. 1989, 'Christian stewardship of possessions - Compelled by the love of Christ', paper delivered at the Wisconsin Lutheran Seminary Faculty Retreat, Maritime Inn, Manitowoc, viewed 12 August 2013, from http:///www. wlsessays.net

Van der Walt, J.L., 2012, 'Another look at education from a Christian stewardship perspective', Koers 77(2), Art. \#428, 7 pages. http://dx.doi.org/10.4102/koers. v77i2.428

Verhoef, P.A., 1987, The books of Haggai and Malachi, Eerdmans, Grand Rapids. (New International Commentary on the Old Testament).

Wells, R.C., 1987, 'The subtle crises of secularism: Preaching the burden of Israel', Criswell Theological Review 2(1), 39-61.

Weyde, K.W., 2000, Prophecy and teaching: Prophetic authority, form problems, and the use of traditions in the book of Malachi, Walter de Gruyden, Berlin. (Beihefte zur Zeitschrift für die Alttestamentliche Wissenschaft, 288).

Williamson, H.G.M., 2004, Studies in the Persian period history and historiography, Mohr Siebeck, Tübingen. (Forschungen zum Alten Testament, 38).

Wretlind, D.O., 2006, Shekels, dollars and sense: A biblical theology of financial stewardship, Trafford Publishing, Victoria.

Wright, C.J.H, 1983a, An eye for an eye: The place of Old Testament ethics today, InterVarsity Press, Downers Grove.

Wright, C.J.H, 1983b, Living as the people of God: The relevance of Old Testament ethics, Inter-Varsity Press, Leicester. 